\title{
NEW DATA ON MACROMYCETE SPECIES (BASIDIOMYCOTA) IN MACEDONIA
}

\author{
Mitko Karadelev*, Katerina Rusevska \\ Institute of Biology, Faculty of Natural Sciences and Mathematics, Ss. Cyril and Methodius University, \\ Skopje, Republic of Macedonia \\ ${ }^{*}$ Corresponding author, e-mail: mitkok@pmf.ukim.mk
}

\begin{abstract}
A study of mycodiversity in Macedonia is underway. The interest in macrofungi studies in Macedonia has been growing in the past 20 years. According to the research conducted up to now, approximately 2,500 macromycetes species have been recorded in the country. A half of this number is a result of the field and taxonomic work in the Mycological Laboratory in the last decade. This work represents a contribution to the Macedonian mycobiota with some rare fungi species.
\end{abstract}

Key words: new data; Basidiomycota; Macedonia

\section{INTRODUCTION}

The Republic of Macedonia is mycologically well investigated. Recently, mycological studies with special emphasis on systematical researches in various groups, such as: Amanita, Peniophora, Phellinus, bolets, morels, Pyrenomycetes, hypogeous fungi, has been conducted by the following authors (Karadelev et al. [1-5], Lambevska et al. [6], Karadelev \& Rusevska [7], Kajevska et al. [8], Chavdarova et al. [9]). In addition, phylogenetic analyses and assessment of antioxidant activities for certain fungi species have been provided (Martín et al. [10], Rusevska et al. [11, 12], Nikolovska-Nedelkoska et al. [13]). The large data amount enabled us to update the preliminary Red List of fungi (Karadelev \& Rusevska [14]). On the basis of the research done so far, 2,500 macromycetes species have been recorded in the Republic of Macedonia. The majority of the species $(1,300)$ belong to the class Basidiomycetes, and 200 species to the class Ascomycetes.

\section{EXPERIMENTAL SECTION}

The data sources used are as follows: exsiccatae and notes from our own studies, the Macedonian
Collection of Fungi (MCF), the database (MAK FUNGI), as well as specimens from other collectors.

The determination of the species was performed during the field research and in the Mycological Laboratory of the Institute of Biology at the Faculty of Natural Science in Skopje, microscopically, by using reagents (Melzers reagent, $\mathrm{KOH}$, Cotton blue, Congo Red, sulphovanillin etc.). Certain species were identified while still in a fresh condition, and the others were to undergo further laboratory analyses. Part of the samples was preserved and deposited in MCF, while all indispensable data about the species were stored in the MACFUNGI database. The identification of the species was carried out using Jülich [15], Allesio [16], Breitenbach \& Kranzlin [17, 18], Hansen \& Knudsen [19], Fernández [20], Krieglsteiner [21, 22], Horak [23], Galli [24] and Knudsen \& Vesterholt [25]. The species names follow Index Fungorum (Kirk, 2016) and MycoBank (Stalpers \& Cock, 2016). The species are reported in alphabetical order. All important data pertaining to geographical distribution, altitude, forest association, and data source are provided under each species. The species distribution map was generated in ArcGIS 10.1 based on Digital Elevation Model (ASTERGDEM) (http://asterweb.jpl.nasa.gov/gdem.asp, 09. 2012). 


\section{RESULTS AND DISCUSSION}

A list of 15 taxa with important data (localities, associations and/or substrates) and distribution maps is presented.

1. Amanita crocea var. subnudipes Romagn.

Skopska Crna Gora: Brodec vill. (vicinity), Quercus forest, soil, 1400 m a.s.1., 16.06.2016.

Papradishte vill. (vicinity), footpath to Solunska Glava, oak forest, soil, $900 \mathrm{~m}$ a.s.l., 19.06.2016.

2. Amanita verna var. decipiens Trimbach

Skopska Crna Gora: Brodec vill. (vicinity), Fagus forest, soil, 1400 m a.s.1., 16.06.2016.

3. Arrhenia griseopallida (Desm.) Watling (syn. Omphalina griseopallida (Desm.) Quél.)

Ljubanci vill., along r. Ljubanska Reka, Quercus forest with Populus and Salix, $900 \mathrm{~m}$ a.s.l., 11.03.2016.

4. Lachnella alboviolascens (Alb. \& Schwein.) Fr.

Markova Reka, yard, Clematis vitalba (fallen branch), 21.02.2016.

5. Leucocoprinus birnbaumii (Corda) Singer (Figure 3)

Skopje: Botanical Garden, pot, soil, $250 \mathrm{~m}$ a.s.1., 28.06.2010.

\section{Leucopaxillus lepistoides (Maire) Singer}

Kumanovo (vicinity): Studena Bara vill., hill pasture, soil, 17.10.2008;

Skopska Crna Gora Mt.: Ljubanci vill., meadow, soil, $800 \mathrm{~m}$ a.s.1., 26.04.2010; Pobozhje vill. (vicinity), soil, 27.05.2010 meadow;

Pijanec: Delchevo, soil, 15.08.2014

7. Marasmius buxi Quél.

Taorska Klisura and Badar: between the monasteries of St. Bogorodica and St. Ilija, azonal vegetation (Buxus, Phillyrea, Qurcus, Carpinus), Buxus (fallen leaves), 03.05.2012.

8. Neolentinus schaefferi (Weinm.) Redhead \& Ginns (Lentinus cyathiformis (Schaeff.) Bres.)

Skopsko Pole: Saraj, park, Populus, 06.04.2016, 09.05.2016.

9. Phaeogalera dissimulans (Berk. \& Broome) Holec (syn. Pholiota oedipus (Cooke) P. D. Orton)

Vodno, deciduous forest (? Tilia sp.), leaves litter, 24.02.2016.
10.Pholiota highlandensis (Peck) Quadr. \& Lunghini (Ph. carbonaria (Fr.) Singer non A. H. Sm.)

Jasen reserve: Selishte, Plocha, Pinetum (burned) with Acer, 1180 m a.s.1., 14.10.2010;

Taorska Klisura and Badar: Kozhle vill. (below), azonal vegetation, sandy soil, 05.04.2016.

11.Pholiota populnea (Pers.) Kuyper \& Tjall.-Beuk.

Skopska Crna Gora Mt.: Banjani vill., at roadsides, Populus (trunk), 800 m a.s.1., 25.09.2005; Ljubanci vill., above the monastery of St. Nikola, deciduous forest with chestnut plantings, Castanea sativa? (fallen trunk), 800-900 m a.s.l., 07.10.2007, Рориlus, (fallen trunk), 18.10.2009.

Kumanovo (vicinity): by the r. Pchinja, Pinus plantings, unknown substrate, 29.10.2007;

Vodno: between Sredno Vodno and the peak, mixed forest, deciduous tree.

\section{Resupinatus trichotis (Pers.) Singer}

Kozhuf Mt.: Umida, deciduous tree, rotten wood, $800 \mathrm{~m}$ a.s.1., 29.04.2002;

Osogovski Planini Mt.: Sasa vill. (vicinity), Quercettum frainetto-cerris, Quercus frainetto (fallen branch), $685 \mathrm{~m}$ a.s.l., 09.04.2008;

Dobra Voda Mt.: Quercettum frainettocerris, Salix sp. (fallen branches), 850-900 m a.s.l., 21.01.2009;

Skopje: Flower market, park, unknown tree (fallen branch), $250 \mathrm{~m}$ a.s.1., 09.11.2009.

13.Rubroboletus rubrosanguineus (Cheype) Kuan Zhao et Zhu L. Yang (Fig. 4)

German, Fagus forest, soil, $1400 \mathrm{~m}$ a.s.l., 02.07.2016.

\section{Xerocomus ichnusanus Alessio}

Kumanovo (vicinity): Vojnik vill., Salix and Populus forest, soil, $311 \mathrm{~m}$ a.s.l., 17.04.2011;

Galičica Mt.: Leskoec vill. (above), Quercetum frainetto-cerris, soil, $1150 \mathrm{~m}$ a.s.l., 13.10.2011.

\section{Xerocomus persicolor H. Engel (Fig. 5)}

Skopska Crna Gora: Brodec vill. (vicinity), Quercus and Fagus forest, soil, $1400 \mathrm{~m}$ a.s.l., 16.06.2016.

A total of 15 species, belonging to Basidiomycota, are part of this work, representing new data for Macedonian mycobiota. One third of the species (5) are lignicolous, all found as saprobes (Lachnella alboviolascens, Marasmius buxi, Neolentinus schaefferi, Pholiota populnea and Resupinatus trichotis), while the other 10 are terricolous. 
The following eight species: Amanita verna var. decipiens, Arrhenia griseopallida, Lachnella alboviolascens, Leucocoprinus birnbaumii, Marasmius buxi, Neolentinus schaefferi, Phaeogalera dissimulans and Rubroboletus rubrosanguineus are were found only on single localities, while the other on two or four localities (Figures 1 and 2).

Some of the species are more or less specific to the substrate. Marasmius buxi grows on fallen leaves of Buxus sempervirens. This fungus was collected from one locality, although its host is not so rare in the country. According to the host distribution we expected to find M. buxi on more localities. Pholiota populnea occurs on dead or living poplar wood and more rarely also on other hardwoods. It

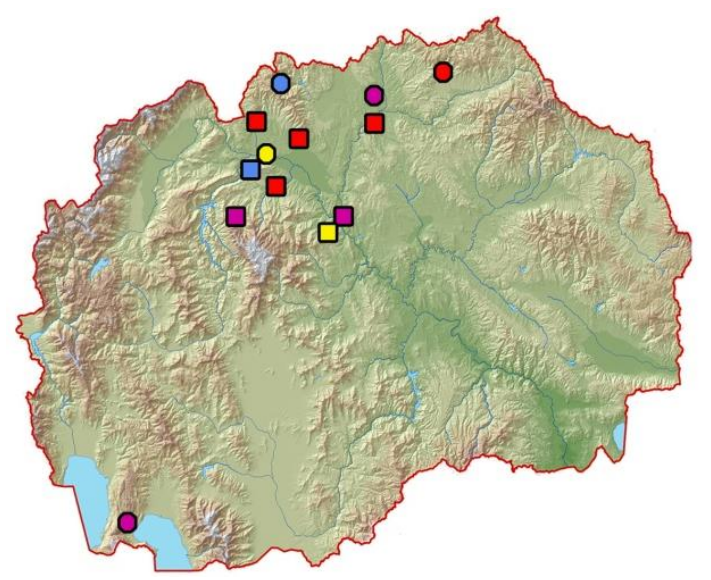

Figure 1. Distribution map of the species: Leucocoprinus birnbaumii $(\mathrm{O})$, Marasmius buxi $(\square)$, Neolentinus schaefferi $(\square)$,Pholiota highlandensis $(\square)$, Ph. populnea $(\square)$, Rubroboletus rubrosanguineus $(\mathbf{O})$, Xerocomus ichnusanus $(\mathbf{O}), X$. persicolor $(\mathbf{O})$. was found on four localities and according to the data available up to now it is a rare species.

Three very rare boletoid species should be pointed out. Xerocomus ichnusanus is a rare thermophilic species distributed in the southern part of Europe, connected mainly to oak forests, but also with other deciduous trees. Our collections originate from oak forest and azonal vegetation with willows and poplars.

Rubroboletus rubrosanguineus is a very rare species, found in the beech forest, on German Mountain. Xerocomus persicolor forms mycorrhiza with oak and beech. It was found only on one locality, in mixed oak and beech forest.

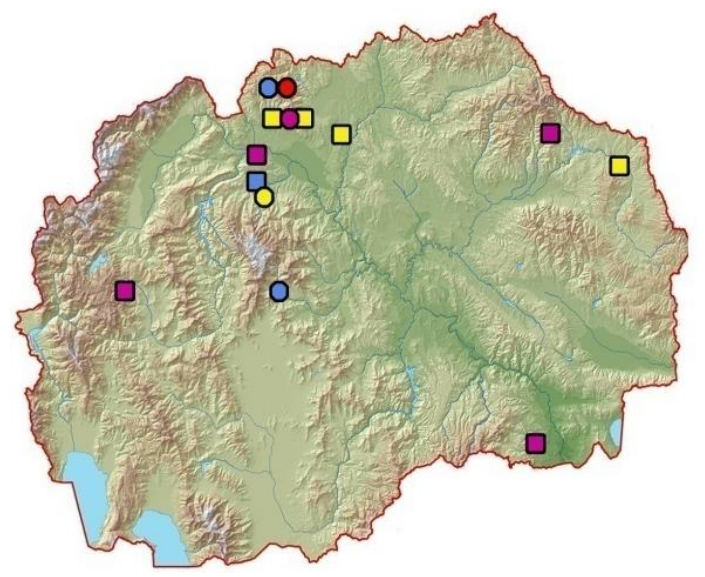

Figure 2. Distribution map of the species: A. crocea var. subnudipes $(\mathbf{O})$, A. verna var. decipiens $(\mathbf{O})$, Arrhenia griseopallida $(\mathbf{O})$, Lachnella alboviolascens $(\mathbf{O})$, Leucopaxillus lepistoides $(\square)$, Phaeogalera dissimulans $(\square)$, and Resupinatus trichotis $(\square)$.

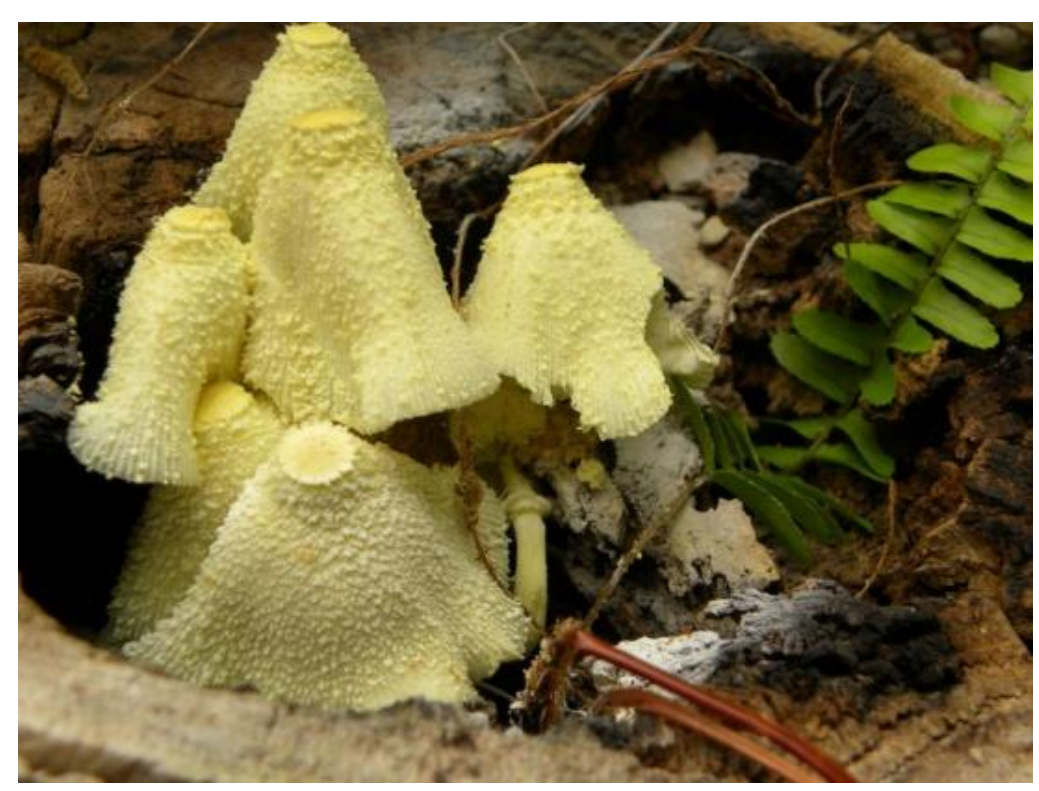

Figure 3. Leucocoprinus birnbaumii, basidiocarps (photo: Mitko Karadelev) 


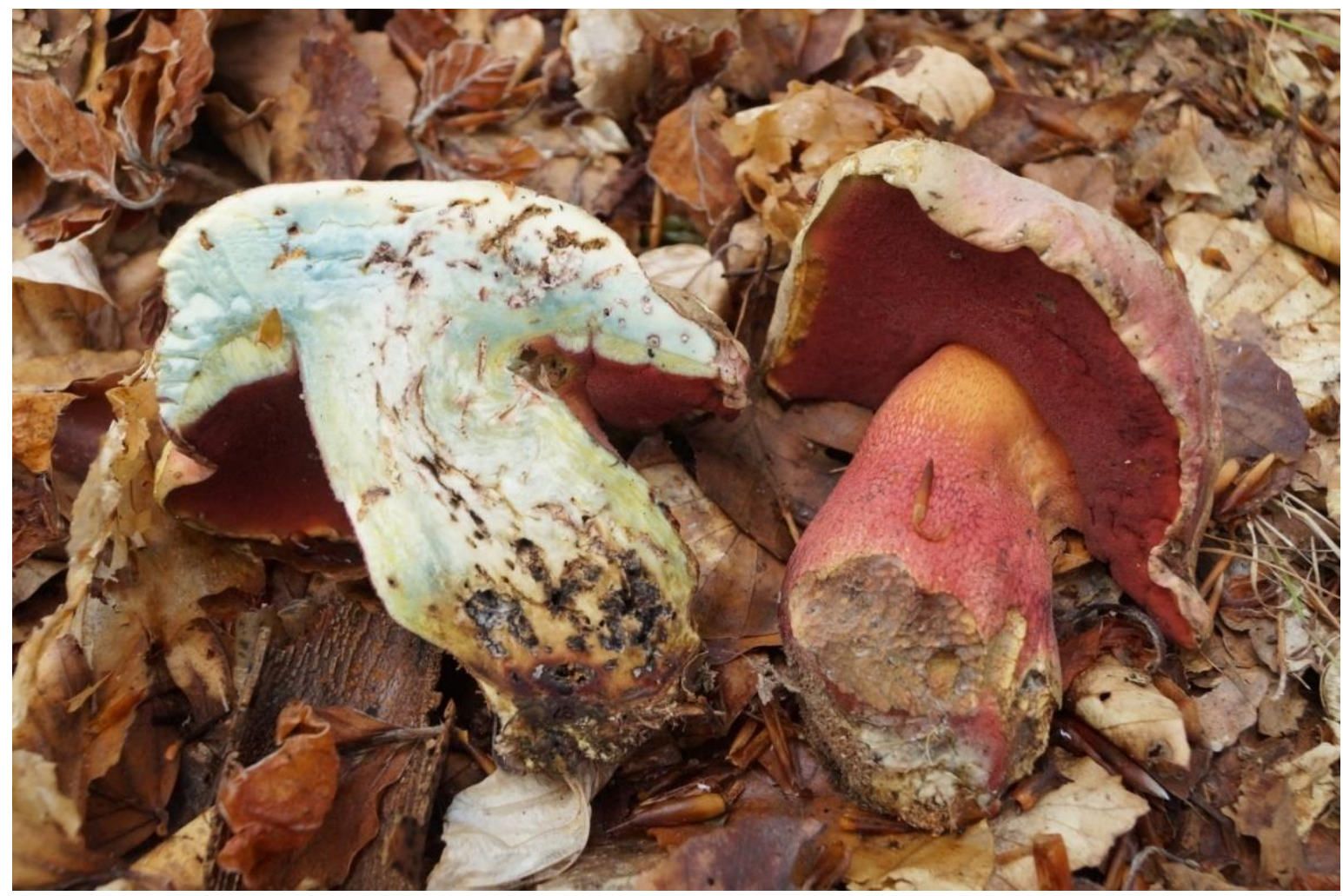

Figure 4. Rubroboletus rubrosanguineus, basidiocarp (photo: Tome Jovanovski)

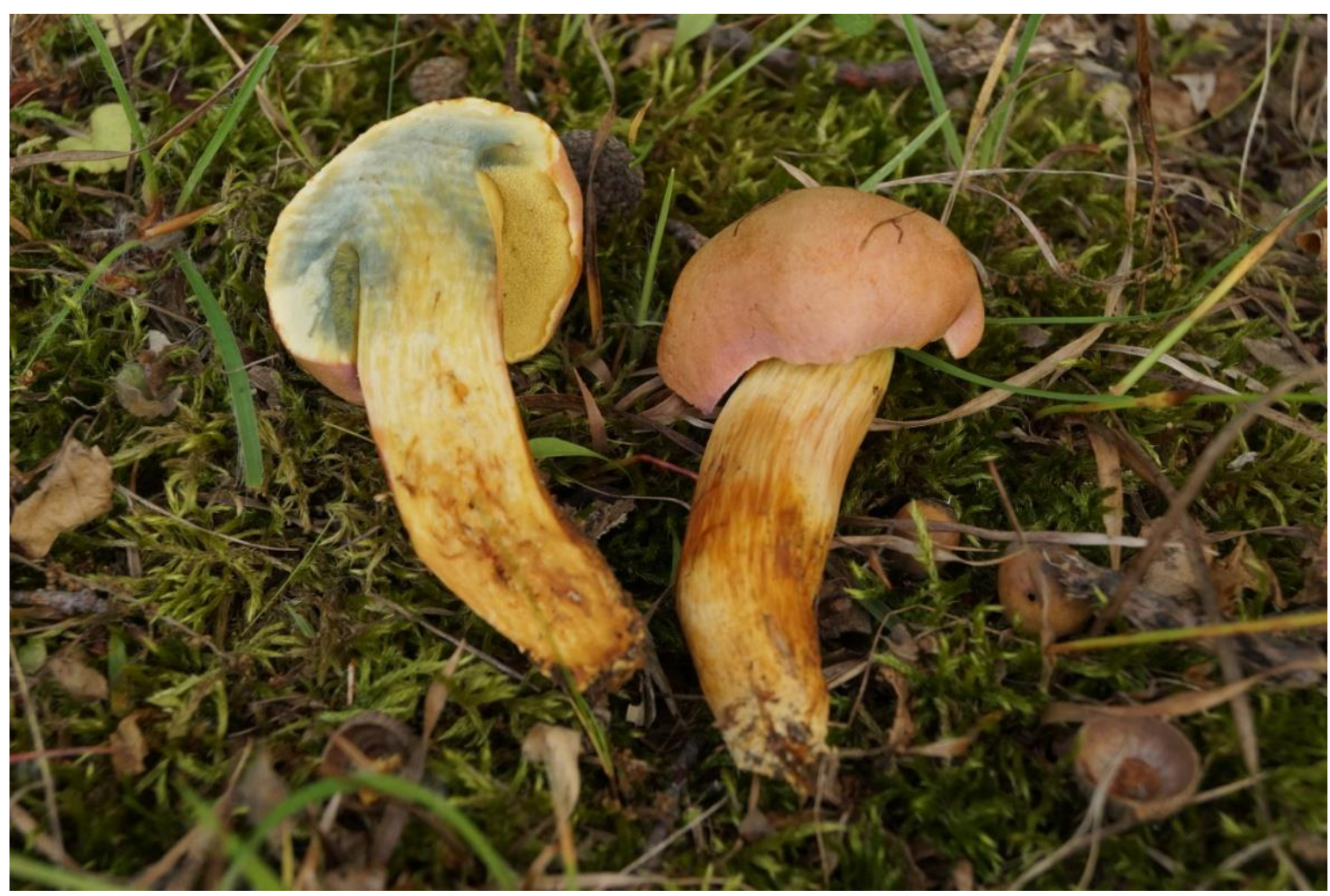

Figure 5. Xerocomus persicolor, basidiocarp (photo: Tome Jovanovski) 
Acknowledgement. We thank Tome Jovanovski for his generous help for collections and photos.

\section{REFERENCES}

[1] M. Karadelev, K. Rusevska, S. Spasikova, Ecology and Distribution of the Genus Boletus L. (Boletaceae) in the Republic of Macedonia, Mycol. Monten., IX (2006), pp. 7-23.

[2] M. Karadelev, K. Rusevska, S. Spasikova, The Boletaceae s.l. (excluding Boletus) in the Republic of Macedonia, Turk. J. Bot., 6, 31 (2007), pp. 539550 .

[3] M. Karadelev, K. Rusevska, S. Stojanovska, Ecology and distribution of Genus Phellinus (Hymenochaetaceae) in the Republic of Macedonia. Proceedings of III Congress of Ecologists of the Republic of Macedonia with International Participation, Struga, 6-9.10.2007, Macedonian Ecological Society, Skopje, 2008, pp. 197-207.

[4] M. Karadelev, K. Rusevska, S. Pampurova, Ecology and distribution of morels (Morchellaceae, Helvellaceae) in the Republic of Macedonia, Ecol. Prot. Env., 12, 1-2 (2009), pp. 45-55.

[5] M. Karadelev, K. Rusevska, V. Cicimov. Distribution and ecology of Genus Amanita (Amanitaceae) in the Republic of Macedonia, Glas. Rep. Zavoda Zašt. Prir. Podgorica, 31-32 (2011), pp. 63-84.

[6] A. Lambevska, K. Rusevska, M. Karadelev, New data on the taxonomy, distribution and ecology of the genus Peniophora Cooke (Basidiomycota, Fungi) in the Republic of Macedonia, Macedonian Journal of Ecology and Environment, 15, 2 (2013), pp. 3-13.

[7] M. Karadelev, K. Rusevska, Bern convention fungi candidates from Macedonia, I (Boletus dupainii, Phylloporus rhodoxanthus and Suillus sibiricus ssp. helveticus), Biol. Macedonica, 61 (2008), pp. 7-14.

[8] I. Kajevska, K. Rusevska, M. Karadelev, The family Pyronemataceae (Pezizales, Ascomycota) in the Republic of Macedonia, Macedonian Journal of Ecology and Environment, 15, 1 (2013), pp. 11-22.

[9] S. Chavdarova, I. Kajevska, K. Rusevska, T. Grebenc, M. Karadelev, Distribution and Ecology of Hypogeous Fungi (excluding Tuber) in the Republic of Macedonia, Biol. Macedonica, 62 (2011), pp. 37-48. Skopje, Macedonia.

[10] M. P. Martín, K. Rusevska, M. Dueñas, M. Karadelev, Battarrea phalloides in Macedonia: genetic variability, distribution and ecology, Acta Mycologica, 48, 1 (2013), pp. 113-122. DOI: $10.5586 / \mathrm{am} .2013 .013$

[11] K. Rusevska, M. Karadelev, C. Phosri, M. Dueñas, R. Watling, M. P. Martín, Rechecking of the genus
Scleroderma (Gasteromycetes) from Macedonia using barcoding approach, Turk. J. Bot., 38, 2 (2014), pp. 375-385. DOI:10.3906/bot-1301-36.

[12] K. Rusevska, M. Karadelev, C. Phosri, M. Dueñas, M. Teresa Telleria, R. Watling, M. P. Martín, DNA barcoding is an effective tool for differentiating Pisolithus species from Macedonia, Mycotaxon, 130 (2015), pp. 1007-1016. http:// 10.5248/130.1007.

[13] D. Nikolovska-Nedelkoska O. Tusevski, K. Rusevska, S. Gadzovska Simic, M. Karadelev, Correlation between antioxidant capacity and phenolic contents of selected bolets from Macedonia. Horizons, International Scientific Journal, Series B, Natural Sciences and Mathematics, Engineering and Technology, Biotechnology, Medicine and Health Sciences, X, 1 (2014) pp. 163-172.

[14] M. Karadelev, K. Rusevska, Contribution to Macedonian Red List of fungi, Proceedings of the $4^{\text {th }}$ Congress of Ecologists of Macedonia with International Participation, Ohrid, 12-15 October 2012, Macedonian Ecological Society, Special issue, Skopje, 28 (2013), pp. 68-73.

[15] W. Jülich, Die Nichtblätterpilze, Gallertpilze und Bauchpilze. Kleine Kryptogamenflora 2b/1, Gustav Fischer Verlag, Stuttgart. 1984.

[16] C. L. Allesio, Boletus Dill. ex L., Giovanna Biella, Italia, 1985.

[17] J. Breitenbach \& F. Kranzlin, Fungi of Switzerland, Volume 3, Edition Mycologia, Switzerland, 1991.

[18] Breitenbach \& Kranzlin, Fungi of Switzerland, Volume 4, Edition Mycologia, Switzerland, 1995.

[19] L. Hansen \& H. Knudsen (eds), (1992). Nordic Macromycetes. Vol. 2. (Polyporales, Boletales, Agaricales, Russulales). Helsinki, 1992.

[20] J. M. R. Fernández, Orden Boletales en España (Boletus Dill. ex Lin., Gomphidius Fr., Paxillus Fr.) - Guia Micologica. Tomo N01. ServisistemEuskoprinter, 1997.

[21] G. J. Krieglsteiner, Die Großpilze BadenWürttembergs, Bd. 2. Verlag Eugen Ulmer GmbH \& Co., Stuttgart, 2000.

[22] G. J. Krieglsteiner, G. J. Die Großpilze BadenWürttembergs, Band 4. Verlag Eugen Ulmer $\mathrm{GmbH} \&$ Co. Stuttgard, 2003.

[23] E. Horak, Rörlinge und Blätterpilze in Europa, 6. Auflage, Elsevier GmbH, München, 2005.

[24] R. Galli, Le Amanite, Edinatura, Milano, 2007.

[25] H. Knudsen \& J. Vesterholt (eds), Funga Nordica (agaricoid, boletoid, clavarioid, cyphelloid and gastroid genera), Nordsvamp, Copenhagen, 2012. 
НОВИ ПОДАТОЦИ ЗА МАКРОМИЦЕТИТЕ (ВАSIDIOМYСОТА) ВО МАКЕДОНИЈА

\section{Митко Караделев, Катерина Русевска}

Институт за биологија, Природно-математички факултет, Универзитет „Св. Кирил и Методиј“,Скопје, Република Македонија

Истражувањата на микодиверзитетот во Македонија се во тек. Во последните дваесетина години се посветува особено внимание на диверзитетот на макромицетите во Македонија. Според податоците од досегашните истражувања за Македонија се познати околу 2500 видови макромицети. Приближно половина од нив се резултат на интензивните теренски и лабораториски истражувања во однос на нивната таксономија во последната декада. Овој труд претставува прилог кон микодиверзитетот на Македонија, во кој се претставени некои ретки видови габи.

Клучни зборови: нови податоци; Basidiomycota; Македонија 